\title{
PREDIKSI HUJAN BULANAN PADA PERIODE ENSO (EI NIŇO SOUTHERN OSCILLATION) MENGGUNAKAN ANFIS (ADAPTIVE NEURO-FUZZY INFERENCE SYSTEM) DI BANJARMANGU, BANJARNEGARA
}

\author{
Monthly Rain Prediction for ENSO (EI Niño Southern Oscillation) \\ Period using ANFIS (Adaptive Neuro-Fuzzy Inference System) in \\ Banjarmangu, Banjarnegara
}

\author{
Agus Safril $^{1{ }^{*}}$, Fakhrul Kurniawan ${ }^{2)}$, Rista Hernandi Virgianto ${ }^{1)}$ \\ 1) Program Studi Klimatologi, Sekolah Tinggi Meteorologi Klimatologi dan Geofisika. Jalan \\ Perhubungan I No.5 Pondok Betung, Bintaro,Tangerang Selatan Banten \\ ${ }^{2)}$ Program Studi Teknik Informatika, UIN Malang. Jalan Gajayana No. 50 Malang 65144. \\ *E-mail: agus.safril@stmkg.ac.id
}

\begin{abstract}
Intisari
Akurasi prediksi curah hujan yang tinggi diperlukan untuk mendapatkan informasi yang tepat dan bermanfaat untuk tindakan mitigasi bencana alam oleh masyarakat. Untuk mendapatkan akurasi yang tinggi diperlukan variabel prediktor yang secara fisis terkait erat dengan curah hujan dan dapat menangkap pola anomali curah hujan akibat El Niňo Southern Oscillation (ENSO). Total Column Water (TCW) sebagai variabel prediktor yang dipilih merupakan potensi uap air di atmosfer yang berpeluang menjadi hujan yang jatuh di permukaan bumi. Data TCW merupakan data reanalisis Model Sirkulasi Global (Global Circulation Model) yang diambil dari European Centre for Medium-Range Weather Forecasts (ECMWF). Analisis korelasi dilakukan untuk mendapatkan tingkat keterhubungan antara prediktor dengan curah hujan. Model prediksi Adaptive Neuro Fuzzy Inference System (ANFIS) digunakan untuk memprediksi curah hujan yang bersifat chaotic. Hasil penelitian menunjukkan pola klimatologis prediktor TCW sesuai pola curah hujan klimatologis dengan kekuatan relasi (r) 0,79. Hasil penelitian menunjukkan pola klimatologis prediktor TCW mengikuti pola curah hujan klimatologis dengan kekuatan relasi $r(0,79)$ pada skala bulanan dan $r(0,73)$ pada skala dasarian. Korelasi antara prediksi dan curah hujan observasi sebesar 0,82. Korelasi paling rendah pada saat terjadi pola Normal, El Niňo dan La Niňa pada tahun 2016 yakni 0,69, diikuti tahun 2014 saat Fase Normal dan El Niňo sebesar 0,77, dan saat El Niňo dominan mencapai korelasi tertinggi yaitu 0,93 di tahun 2015. Pada prediksi hujan skala dasarian menunjukkan tingkat keandalan yang tidak jauh berbeda dengan prediksi hujan bulanan dengan nilai $r(0,65)$ pada periode La Niňa dan $r(0,80)$ pada periode El Niňo.
\end{abstract}

Kata Kunci: Prediksi, Total Column Water, ANFIS, ENSO, Banjarnegara

\begin{abstract}
High accuracy in rainfall prediction is needed to obtain appropriate and useful information for natural disaster mitigations by the community. To get higher accuracy, we need a set of predictor variables related to the rainfall, and we can use rainfall anomaly patterns affected by The El Niňo Southern Oscillation (ENSO). The total column water (TCW), as the chosen predictor variable, is the potential for water vapor in the atmosphere, which has the possibility to become droplets falling to the earth's surface. TCW data are the re-analyzed Global Circulation Model data obtained from the European Mid-Term Weather Forecast Center (ECMWF). The correlation analysis was carried out to evaluate the relationship between predictors and rainfall. Adaptive Neuro-Fuzzy Inference System (ANFIS) was used to predict the chaotic rainfall. The results showed that the climatological pattern of TCW predictors was in accordance with the climatological rainfall pattern with the correlation strength (r) 0.79 . The results showed that the climatological pattern of TCW predictors followed the climatological rainfall pattern with a relation strength of 0.79 . The correlation between prediction and observation rainfall is 0.82 . The lowest correlation at the time of the Normal, El Niňo and La Niňa patterns in 2016 was 0.69, followed in 2014 when Normal Phase and El Niňo were at 0.77 , and when EL Niňo was dominant, it reached the highest correlation at 0.93 in 2015 . In the 10day scale, rain predictions show a level of reliability that is not much different from the prediction of monthly rainfall with a value of $r(0.65)$ in the La Niňa period and $4(0.80)$ in the El Niňo period.
\end{abstract}




\section{PENDAHULUAN}

Banjarmangu merupakan salah satu kecamatan di Kabupaten Banjarnegara yang rawan bencana longsor (Priyono dan Priyana, 2006; Warnadi, 2014). Kerawanan longsor yang tinggi di Banjarmangu disebabkan karena kemiringan lereng yang curam (Priyono dan Priyana, 2006; Susanti, et al., 2017) dan curah hujan tinggi (Priyono, 2008; Ridmardhani, 2015; Safril et al., 2017; Susanti dan Miardini, 2016). Hujan memiliki kontribusi terhadap kejadian tanah longsor terutama setelah musim kemarau, air hujan mengisi pori-pori tanah kering yang retak sehingga akan meningkatkan tekanan pori tanah dan meningkatkan potensi longsor bila terjadi di daerah dengan kemiringan lereng tinggi (Hidayat dan Prasetyaningtiyas, 2018; Irawan, et al., 2019; Liliwarti, et al., 2016; Soenarmo, et al., 2008).

Informasi prediksi curah hujan dalam skala lokal yang akurat sangat dibutuhkan di wilayah rawan longsor seperti di Banjarmangu. Beberapa penelitian terdahulu terkait prediksi hujan skala bulanan telah dilakukan Swarinoto et al. (2012); Nuraini et al. (2019); dan Kadarsyah (2010) serta prediksi dasarian menggunakan ANFIS dengan data deret waktu curah hujan hasil transformasi wavelet (Kurnia et al. 2016). Dalam penelitian ini dilakukan prediksi curah hujan untuk skala dasarian dengan prediktor hasil dari pemodelan numerik (reanalysis). Prediktor ini dipilih karena mencerminkan karakteristik fisis atmosfer yang terkait dengan curah hujan di wilayah prediksi. Kelebihan menggunakan prediktor variabel atmosfer adalah ini dapat dikembangkan untuk prediksi beberapa bulan ke depan (Wang et al. 2010). Dalam penelitian ini, untuk mendapatkan keandalan prediksi maka dilakukan analisis pola prediksi saat terjadi anomali iklim (El Niňo dan La Niňa) dibandingkan dengan observasi.

Untuk mendapatkan karakteristik lokal, maka dilakukan analisis keterkaitan variabel atmosfer dengan curah hujan wilayah prediksi. Analisis antara dua set variabel (prediktor variabel atmosfer dan curah hujan) melalui analisis statistik yang dilakukan pada data historis sebagai deret waktu (time series) (Deliang dan Inger, 2008; Schmidli et al., 2006).

Akurasi yang tinggi diperlukan untuk mendapatkan kepercayaan bagi pengguna prakiran. Oleh karena itu, untuk mendapatkan keandalan model prediksi diperlukan prediktor yang secara fisis terkait erat dengan variabilitas curah hujan di daerah prediksi. Variabilitas hujan di Benua Maritim-Asia Tenggara dipengaruhi kuat oleh siklus iklim tahunan dan musiman (Chang, et al., 2005). Variabilitas hujan di wilayah Indonesia khususnya di Pulau Jawa sangat erat kaitannya dengan fenomena El-Niňo Southern Oscillation atau yang biasa disebut dengan ENSO (Hamada, et al., 2012; Hidayat, et al., 2016; Qian, et al., 2010).

Pada saat periode ENSO, terjadi variabilitas uap air yang tinggi ketika La Niňa dengan distribusi uap air banyak di wilayah benua Maritim (Susanti, 2017). Sedangkan pada saat El Niňo kandungan uap air di wilayah benua maritim berkurang sehingga curah hujan di bawah keadaan rata-ratanya (Nur'utami dan Hidayat, 2016). Hal ini menegaskan bahwa variabilitas curah hujan di Indonesia sangat dipengaruhi oleh fenomena ENSO.

Penelitian Manzanas

(2017) menggunakan variabel prediktor precipitable water (Total Column Water) untuk memprediksi curah hujan. Prediktor ini menggambarkan kondisi fisis dan dinamis atmosfer digunakan keluaran model numerik (Numerical Weather Prediction). Sedangkan untuk menangkap pola anomali tersebut diperlukan model prediksi yang dapat menangkap pola curah hujan tidak teratur (chaotic) akibat fenomena ENSO tersebut. Model prediksi dengan ANFIS (Adaptive NeuroFuzzy Inference System) digunakan untuk memprediksi pola yang bersifat chaotic (Jang, 1993; Soto, et al., 2010). Model sistem pendukung keputusan Fuzzy digunakan dalam berbagai bidang (Kurniawan, et al., 2017) termasuk juga dalam bidang prediksi cuaca ((Kinasih, et al., 2015; Navianti dan Widjajati, 2012; Pandey, et al., 2017; Riordan dan Hansen, 2002).

Berdasarkan latar belakang tersebut, maka sebuah model prediksi diperlukan untuk memperkirakan pola anomali curah hujan khususnya di Banjarmangu dengan menggunakan prediktor yang secara fisis terkait dengan proses terjadinya hujan. Penelitian ini bertujuan untuk mendapatkan model yang dapat memprediksi anomali curah hujan akibat ENSO dalam skala lokal. Prediktor yang digunakan adalah potensi uap air yang ada di atmosfer yang dapat mempengaruhi curah hujan yang akan turun.

\section{METODE}

\subsection{Data}

Lokasi penelitian berada di Kecamatan Banjarmangu Kabupaten Banjarnegara. Karakteristik bentang alam Banjarnegara terdiri dari wilayah pegunungan. Data curah hujan diperoleh dari Badan Meteorologi Klimatologi dan Geofisika Stasiun Geofisika (BMKG) Banjarnegara seperti di Gambar 1. Periode curah hujan yang digunakan untuk penelitian ini adalah hujan bulanan tahun 1997-2016. Data latih untuk prediksi dengan periode 1997-2014 dan data untuk verifikasi hasil prediksi 20142016 (tiga tahun). Data curah hujan diperoleh dari data pengamatan harian yang dijumlah dalam satu bulan. Untuk analisis ENSO 
digunakan Data Ocean Niňo Index (ONI) diperoleh dari National Oceanic and Atmospheric Administration (NOAA, 2020).

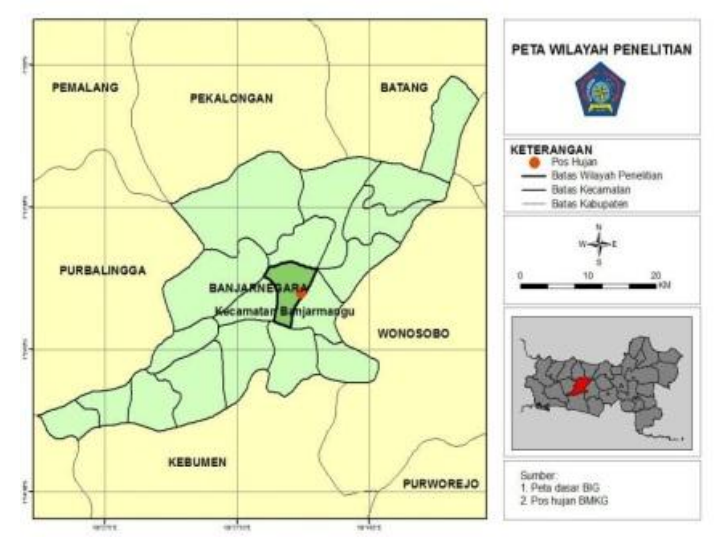

Gambar 1. Lokasi Penelitian Kec. Banjarmangu, Kabupaten Banjarnegara.

Dalam penelitian ini, model prediksi menggunakan data reanalisis dari tahun 19972016. Data latih menggunakan data curah hujan dan prediktor keluaran model numerik bulanan dari data reanalisis data Total Column Water (TCW), luaran European Centre for MediumRange Weather Forecasts (ECMWF) dengan resolusi 12,5 kilometer dengan periode 1997 2013 dan data untuk prediksi 2014-2016 terdiri atas data air mampu curah atau TCW dengan satuan $\mathrm{kg} / \mathrm{m}^{2}$. TCW adalah Integral vertikal dari tanah ke puncak nominal atmosfer yang menyatakan jumlah total air (uap air+ awan air+awan es), tetapi tidak ada curah hujan (ECMWF, 2020). Parameter ini adalah jumlah total uap air dalam kolom yang memanjang dari permukaan bumi ke atas atmosfer. Parameter ini mewakili nilai rata-rata area untuk kotak grid. Contoh data TCW secara spasial sebagaimana Gambar 2. Warna merah menunjukkan kandungan uap air yang tinggi, hijau dan kuning menunjukkan kandungan uap air sedang, serta biru dan ungu menunjukan kandungan uap air rendah. Data latih untuk prediksi diambil satu titik grid pada koordinat lokasi penelitian $-7,36^{\circ}$ LU dan $109,69^{\circ}$ BT. Data curah hujan dan TCW selanjutnya dibuat dalam deret waktu.

\subsection{Metode}

Pembangunan model Prediksi terdiri dari analisis keterkaitan antara prediktor dan prediktan, model prediksi dan verifikasi model

\subsubsection{Karakteristik fisis TCW}

Studi ini bertujuan untuk mendapatkan karakteristik fisis precipitable water (TCW) terkait dengan curah hujan. Pola distribusi TCW menunjukkan mampu menangkap fitur skala besar sistem curah hujan monsun dan bermanfaat dalam prediksi kejadian hujan lebat (Durai, et al., 2007). Keterkaitan dengan pola sinoptik juga ditunjukkan dari nilai korelasi positif yang signifikan pada skala musiman yang menyiratkan bahwa TCW memiliki kemampuan untuk menunjukkan variasi antar tahunan interannual dari onset dan akhir monsun (Lu et al., 2015). Secara tren jangka panjang curah hujan di Tiongkok dapat dikaitkan dengan tren precipitable water di tingkat bawah dan menengah (Xie et al., 2011).

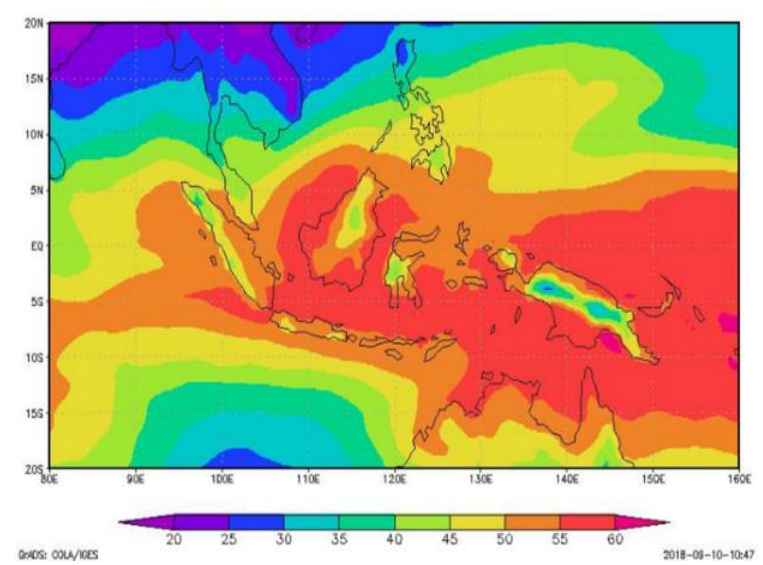

Gambar 2. Data TCW (Total Column Water) Lokasi Data penelitian wilayah Indonesia $\left(\mathrm{kg} / \mathrm{m}^{2}\right)$.

Secara dinamis transport uap air terkait dengan curah hujan menunjukkan bahwa $72 \%$ (76\%) dari kuartil teratas (desil) hari hujan musim terjadi dalam kondisi dengan transportasi uap air pada hari sebelumnya (Ralph dan Galarneau Jr, 2017). Selain itu, perbandingan fluks uap air yang terintegrasi secara vertikal dan perbedaannya antara musim hujan yang paling basah dan paling kering menunjukkan bahwa kelayakan spasial uap air pada musim hujan dipengaruhi oleh sirkulasi atmosfer berskala besar (Lu et al., 2015). Dalam siklus monsun, Intensitas monsun Asia Timur musim panas dan peristiwa El Niňo terdapat korelasi positif dengan uap air (Wang dan Chen, 2012). Uap air memiliki energi laten yang besar pada perubahan fase uap air secara signifikan mempengaruhi stabilitas vertikal, dan keseimbangan energi atmosfer.

Dari studi pustaka tersebut disimpulkan bahwa precipitable water: Berdasarkan pertimbangan tersebut maka TCW dijadikan prediktor yang terkait secara fisis dengan curah hujan.

\subsubsection{Analisis keterkaitan variabel prediktor TCW dengan curah hujan}

Variabel bebas (respon) atau dependent, menentukan pengaruh dari variabel independen. Nilai variabel bebas bisa menentukan besarnya perubahan variabel independen. Dasar pemilihan prediktor adalah hubungan sebab akibat antara prediktor dan prediktan (curah 
hujan). Pola hubungan ini dinyatakan dengan analisis korelasi uap air sebagai salah satu komponen atmosfer yang penting dan mempunyai pengaruh terhadap pembentukan curah hujan seperti pada penjelasan dahulu. TCW menentukan mekanisme transpor kelembaban dan variabilitas monsun dalam beberapa dekade terakhir (Bordi et al., 2015). Selain faktor fisis, analisis statistik dilakukan dengan analisis pola rata-rata tahunan curah hujan dan TCW untuk mendapatkan pola umum prediktor dan prediktan. Analisis kekuatan hubungan dengan metode korelasi juga dilakukan antara variabel bebas (TCW) dan bergantung (curah hujan) di wilayah prediksi. Analisis korelasi menggunakan korelasi Pearson dengan hubungan dikatakan kuat bila mendekati 1 dan lemah bila mendekati 0 . Hubungan dikatakan lemah apabila nilai $r$ kurang dari 0,33, sedang 0,33-0,66, dan kuat bila $r>0,3$. Nilai korelasi Pearson dinyatakan dengan persamaan berikut,

$$
r=\frac{\sum x y-\frac{\left(\sum x i \omega y\right.}{n}}{\sqrt{\left(\sum x^{2}-\frac{\left(\sum x\right)^{2}}{n}\right)\left(\sum y^{2} \frac{\left(\sum y\right)^{2}}{n}\right)}}
$$

1. Variabel yang dapat untuk menangkap perubahan iklim

2. Dapat mendeteksi hujan lebat

3. Terkait dengan monsoon

4. Dipengaruhi oleh sirkulasi global

5. Mempengaruhi dinamika atmosfer vertikal

\subsubsection{Pembangunan Model Prediksi}

Metode prediksi curah hujan bulanan menggunakan Adaptive Neuro-Fuzzy Inference System (Jang, 1993) dapat dilihat di Gambar 3. Metode ANFIS dapat menangkap pola hujan yang tidak beraturan (chaotic). Model prediksi ANFIS dibangun dari aplikasi Matlab (Matrix Laboratory) berbasis Windows.

Data latih antara input (TCW) dan keluaran (curah hujan) pada periode tahun 1997-2011. ANFIS memiliki kemampuan untuk menangani sistem non linear dan berubah terhadap waktu (adaptif). Model ANFIS dibangun dengan kombinasi antara logika fuzzy dan jaringan syaraf tiruan (backpropagation). Model fuzzy adalah sebuah metode pembobotan dengan variabel $x$ (linguistic) sebagai pengganti berhitung bilangan contoh tinggi dan rendah.

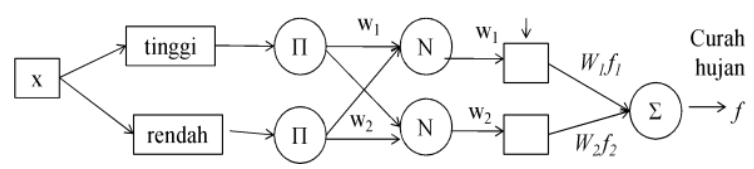

Gambar 3. Struktur lapisan ANFIS untuk prediksi curah hujan.
Lapisan 1 merupakan lapisan fuzzifikasi, setiap node $i$ pada lapisan ini adalah node adaptif dengan fungsi node $O_{i}^{1}=\mu A i(x)$ dengan $x$ adalah masukan ke node $i$. Sedangkan $A i$ dan $B_{i}$ adalah label linguistik (tinggi, rendah, dan sebagainya) yang sesuai dengan fungsi node sebagai bentuk fungsi keanggotaan. Bentuk fungsi keanggotaan dalam bentuk Bell (lonceng) sebagai berikut,

$\operatorname{\mu Ai}(x)=\frac{1}{\left.1+\left[\left(\frac{x-a i}{a i}\right)\right]\right] b i}$

dengan $\left(a_{i}, b_{i}, c_{i}\right)$ adalah parameter premis yang adaptif.

Di lapisan 2, semua simpul pada lapisan ini adalah non adaptif (parameter tetap) yang berfungsi mengalihkan semua sinyal yang masuk dan mengirim keluaran

$W_{i}=\mu A_{1}(x) x \mu B_{1}(y), i=1,2$.

Setiap node mencerminkan derajat pengaktifan (firing strength) pada setiap aturan.

Lapisan 3: setiap node pada lapisan ini merupakan suatu lingkaran node dengan label $N$. Node ke / dihitung rasio rule ke / dari firing strength untuk jumlah seluruh firing strength

$\underline{w i}=\frac{w i}{w 1+w 2}$.

Dalam lapisan 4, setiap node $i$ pada layer ini dalam bentuk node segi empat dengan sebuah fungsi derajat pengaktifan ternormalisasi dari lapisan tiga dan parameter $p, q, \quad r$ menyatakan parameter konsekuen yang adaptif

$O i=w i f i=w i(p i x+q i y+r i)$

Di lapisan 5 hanya terdapat satu simpul tetap. Setiap node tunggal pada lapisan ini adalah node lingkaran untuk melakukan penjumlahan keluaran dari semua sinyal yang masuk

$\sum w_{i} f_{i}=\frac{\sum i f i}{\sum i w i i^{x}}$

\subsubsection{Verifikasi Hasil Model}

Verifikasi model dilakukan dengan analisis korelasi yaitu curah hujan antara hasil prediksi dan observasi. Analisis korelasi mendekati 1 menunjukan akurasi yang tinggi dan mendekati nilai 0 menunjukkan akurasi rendah. Untuk kebutuhan verifikasi data yang digunakan adalah data curah hujan independen 3 tahun (2014-2016). Tahun prediksi yang diverifikasi mengandung karakter anomali yang disebabkan oleh anomali iklim akibat ENSO yaitu pada tahun-tahun kondisi iklim normal, La Niňa dan El Niňo. 


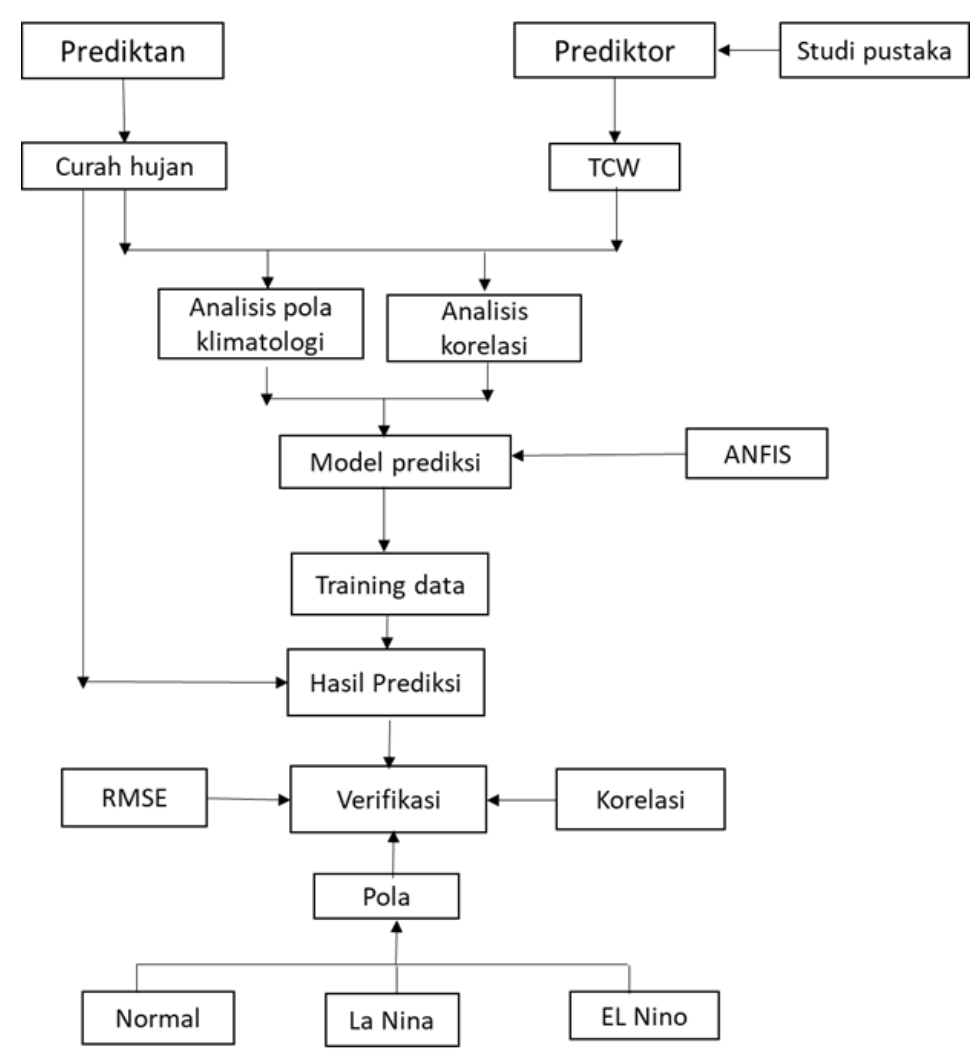

Gambar 4. Diagram alir penelitian prediksi.

Selanjutnya analisis keandalan model menggunakan Root Square Mean Error (RMSE) (Wilks, 2011). Untuk melihat error prediksi yang dibandingkan secara keseluruhan tahun dan setiap tahun. Hal ini untuk mengetahui keandalan model dalam keadaan terjadi anomali iklim.Persamaan RMSE sebagai mana dalam persamaan berikut,

MSE $=\frac{1}{n-u} \sum_{k=1}^{n}\left(y_{k}-o_{k}\right)$

RMSE $=\sqrt{M S E}$.

Secara umum diagram alir penelitian seperti pada Gambar 4 variabel prediktor dan prediktan adalah TCS dan variabel respon (curah hujan), kemudian dilakukan analisis pola klimatologi dan korelasi. Selanjutnya dari apabila nilai korelasi kuat dilanjutkan dengan membangun model prediksi dengan ANFIS. Training data pada ANFIS dengan satu prediktor dan prediktan dengan periode waktu data 19972014 (15 tahun) dan verifikasi data tahun 20152016 (tiga tahun).

Dari hasil prediksi, selanjutnya dianalisis antara hasil prediksi dan curah hujan observasi dengan analisis RMSE dan korelasi. Kemudian, pada tahap akhir dengan analisis pola dengan variabilitas curah yang terjadi saat pola tunggal maupun pola gabungan. El Niňo tunggal, El Niňo bersama dengan La Niňa dan Normal, dan pola ketiga yaitu El Niňo, La Niňa dan kondisi Normal.

\section{HASIL DAN PEMBAHASAN}

\subsection{Kekuatan Relasi Variabel Atmosfer dan Curah Hujan dan Pola Klimatologis}

Hubungan antara prediktor (PW) prediktan menunjukkan keterkaitan yang erat dengan nilai korelasi kuat $(0,79)$. Nilai korelasi ini menunjukkan bila potensi kandungan air di atmosfer meningkat maka curah hujan juga meningkat. Sebaliknya, bila potensi uap air menurun maka curah hujan menurun.

Selain analisis korelasi, juga dilakukan analisis pola klimatologi. Secara umum, pola klimatologis yang diperlukan adalah yang sama antara prediktor dan prediktan. Prediktor yang tidak sesuai sesuai dengan pola curah hujan akan mempengaruhi keandalan prediksi. Oleh karena itu, perlu dibandingkan antara pola curah hujan klimatologi dengan prediktor TCW secara klimatologis. Tipe pola hujan di wilayah Banjarnegara adalah curah hujan monsun dengan puncak hujan satu kali (Aldrian dan Susanto, 2003).

Berdasarkan Gambar 5, jumlah curah hujan kurang dari $150 \mathrm{~mm}$ terjadi pada bulan Juni, Juli, Agustus (JJA) menunjukkan periode musim kemarau. Curah hujan di atas $150 \mathrm{~mm}$ umumnya terjadi pada bulan Desember, Januari, Februari (DJF) yang menunjukkan musim 
penghujan. Dari Gambar 5, pola curah hujan tinggi terjadi 8 bulan berturut-turut. Dengan pola klimatologis ini, curah hujan tinggi terjadi hampir sepanjang tahun.

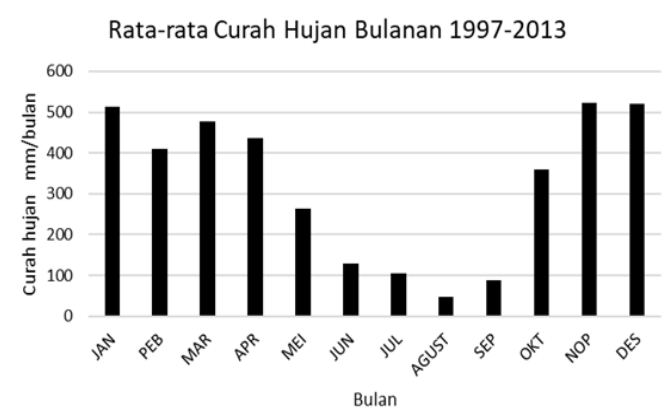

Gambar 5. Pola Hujan bulanan Banjarmangu tahun 1997-2013.

Pola TCW menunjukkan pola monsunal dengan satu puncak dan satu lembah (pola monsunal) seperti pada Gambar 6. Pola terendah pada bulan Agustus dengan kandungan uap air $30 \mathrm{~kg} / \mathrm{m}^{2}$ dan tertinggi pada bulan Februari dan Desember $\left(50 \mathrm{~kg} / \mathrm{m}^{2}\right)$. Pola ini sesuai dengan pola curah hujan monsunal. Dengan kondisi ini, secara klimatologis prediktor TCW mampu mengikuti pola curah hujan observasi sehingga layak digunakan sebagai prediktor.

Rata-rata Total Column Water Bulanan 1997-2013

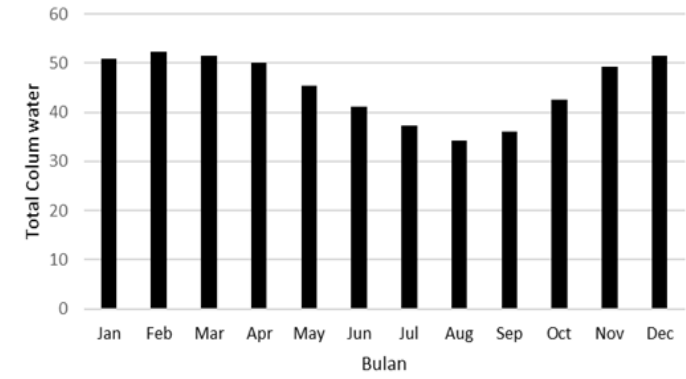

Gambar 6. Pola Klimatologis Total Column Water 1997-2013.

\subsection{Verifikasi Prediksi Hasil Model}

Hasil verifikasi dengan data independen tahun 2014-2016 menunjukkan secara kuantitatif hasil prediksi dianalisis berdasarkan nilai korelasi dan nilai antara prediksi dan observasi serta nilai RMSE. Hasil prediksi dengan metode nilai korelasi prediksi sebesar 0,82. Hasil analisis pola menunjukkan bahwa terjadi fenomena EI Niňo dan La Niňa pada tahun 2014-2016. Kejadian ini dapat dilihat pada Tabel 1 berikut:

Tabel 1. Kejadian ENSO pada tahun 2014-2016.

\begin{tabular}{|c|c|c|c|}
\hline Tahun & Normal & El Niňo & La Niňa \\
\hline 2014 & v & v & - \\
\hline 2015 & - & v & - \\
\hline 2016 & v & v & v \\
\hline
\end{tabular}

Hasil nilai RMSE dan korelasi tiap tahun dianalisis berdasarkan faktor yang dominan pada periode tersebut (normal, El Niňo dan La Niňa). Pada awal tahun 2014, El Niňo terjadi bulan Oktober dan dilanjutkan dengan tahun El Niňo 2015 dari bulan Januari-Desember berlanjut hingga April 2016 dengan nilai indeks positif (indeks>0,5) seperti pada Gambar 7 .

Pada saat ini, kondisi suhu muka laut di wilayah Indeks Niňo 3.4 meningkat sedangkan di wilayah perairan Indonesia mengalami penurunan. Sebagai dampak dari perubahan suhu muka laut tersebut, wilayah perairan Indonesia mengalami pengurangan jumlah awan sehingga curah hujan menurun. Peristiwa La Niňa terjadi pada Agustus-November 2016. Sebaliknya, pada periode La Niňa curah hujan turun akibat mendinginnya suhu muka laut di perairan Indonesia dan memanasnya suhu muka luat di wilayah Niňo 3.4.

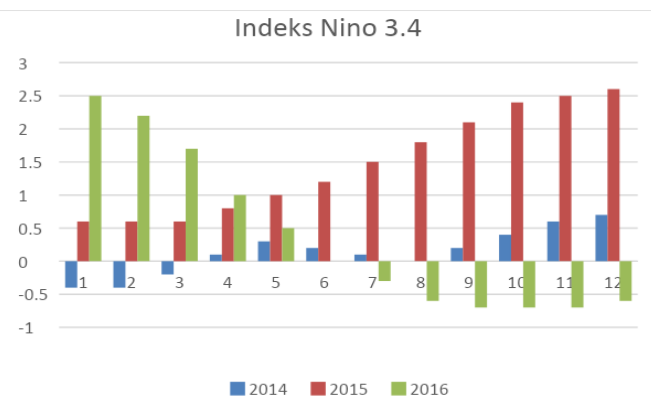

Gambar 7. Indeks Niňo 3.4 tahun 2014-2016.

Hasil prediksi pada periode ENSO dengan prediktor TCW menunjukkan pola prediksi yang mengikuti pola observasi pola musiman. Pada saat musim hujan, curah hujan mencapai puncak pada bulan OktoberNovember dan mencapai nilai terendah pada bulan Juli-September (Gambar 8).

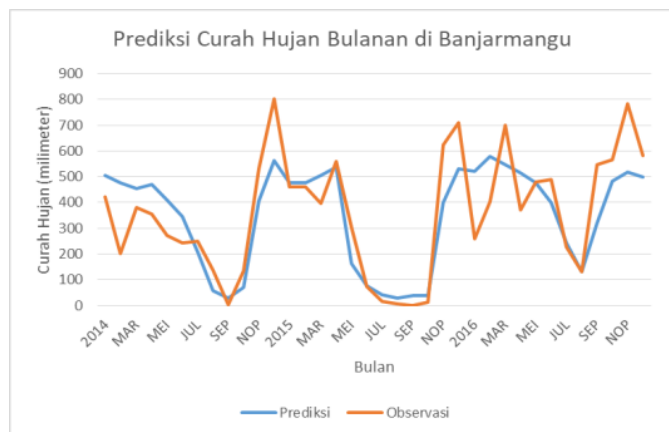

Gambar 8. Hasil prediksi pada periode ENSO.

Hasil analisis RMSE dan korelasi untuk keseluruhan tahun dan per tahun menunjukkan variasi. Pada saat kejadian pola normal, El Niňo, dan La Niňa pada tahun 2016 menunjukkan RMSE rendah dan korelasi rendah. Pada saat pola El Niňo dominan, El Niňo kuat RMSE paling rendah, dan dalam kondisi sedang pada saat tahun El Niňo dan normal terjadi seperti pada Tabel 2. Secara umum, prediksi dengan kategori 
baik terjadi pada saat fenomena iklim El Niňo dan La Niňa. Korelasi tiap tahun yang paling rendah terjadi pada saat pola Normal, El Niňo, dan La Niňa pada tahun 2016 yang sama $(0,69)$, diikuti tahun 2014 saat Normal dan EI Niňo serta saat EI Niňo paling dominan mencapai korelasi tertinggi $(0,93)$ pada tahun 2015. Nilai RMSE juga menunjukkan variasi sesuai dengan nilai korelasi terendah pada tahun 2015, tertinggi pada tahun 2016 dan sedang pada tahun 2014. Hal ini menunjukkan prediksi dengan variabel prediktor dapat menangkap pola anomali curah hujan saat fenomena ENSO terjadi.

Tabel 2. Verifikasi hasil antara hasil prediksi dan observasi.

\begin{tabular}{|c|c|c|c|c|}
\hline & \multicolumn{4}{|c|}{ Tahun } \\
\cline { 2 - 5 } & $\begin{array}{c}\mathbf{2 0 1 4 -} \\
\mathbf{2 0 1 6}\end{array}$ & $\mathbf{2 0 1 4}$ & $\mathbf{2 0 1 5}$ & $\mathbf{2 0 1 6}$ \\
\hline RMSE (mm) & 132 & 134 & 99 & 156 \\
\hline Korelasi & 0,82 & 0,77 & 0,93 & 0,69 \\
\hline
\end{tabular}

Tabel 3. Verifikasi hasil antara hasil prediksi dan observasi.

\begin{tabular}{|c|c|l|l|}
\hline \multirow{2}{*}{$\cdot$} & \multicolumn{3}{|c|}{ Tahun } \\
\cline { 2 - 4 } & $\begin{array}{c}\mathbf{2 0 1 4}- \\
\mathbf{2 0 1 5}\end{array}$ & $\mathbf{2 0 1 4}$ & $\mathbf{2 0 1 5}$ \\
\hline RMSE $(\mathrm{mm})$ & 334 & 369 & 326 \\
\hline Korelasi $(\mathrm{r})$ & 0,73 & 0,65 & 0,80 \\
\hline
\end{tabular}

Untuk mendapat keandalan model, maka prediksi hujan dilakukan dalam skala waktu dasarian (sepuluh harian) di stasiun hujan terdekat (Wanadadi) dengan wilayah Banjarmangu dengan koordinat $7,37^{\circ}$ LS, $109,63^{\circ}$ BT karena iklim bervariasi secara spasial. Hasil prediksi hujan menunjukkan pola prediksi mengikuti pola observasi (Gambar 9). Pola La Niňa ditunjukkan pada tahun 2014 dan pola El Niňo terjadi pada tahun 2015.

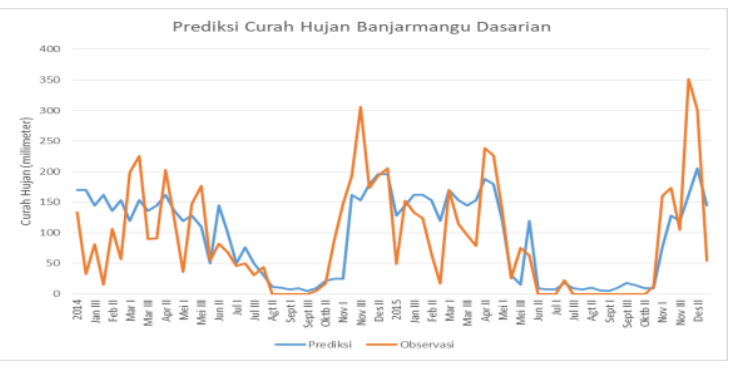

Gambar 9. Hasil prediksi pada periode ENSO.

Analisis statistik keandalan model prediksi curah hujan dasarian dilakukan selama dua tahun (2014 dan 2015) yang mewakili tahun La Niňa dan El Niňo (Tabel 3). Hasil prediksi menunjukkan korelasi tinggi $(0,73)$ dengan $\begin{array}{llllll}\text { korelasi } & 0,65 & \text { (2014) dan } & 0,80 & \text { (2015). }\end{array}$ Keandalan model prediksi pada tahun El Niňo lebih tinggi dari pada La Niňa. Kondisi ini konsisten dengan hasil prediksi bulanan dengan nilai RMSE (334 mm).

\section{KESIMPULAN}

Hasil analisis korelasi menunjukkan keterkaitan kuat $(r>0,66)$ antara prediktor TCW dan curah hujan $(r=0,79)$. Pola monsunal secara klimatologis ditunjukkan oleh rata-rata curah hujan dengan pola yang mirip dengan pola TCW. Pola puncak pada DJF dan lembah pada bulan JJA.

Nilai prediksi curah hujan bulanan menunjukkan pola hujan prediksi dapat menangkap pola EL Niňo nilai korelasi kuat 0,82. Korelasi paling rendah pada saat terjadi pola Normal, El Niňo, dan La Niňa pada tahun 2016 yang sama $(0,69)$, diikuti tahun 2014 saat Normal dan EI Niňo dan saat El Niňo paling dominan mencapai korelasi tertinggi $(0,93)$ pada tahun 2015.

Nilai RMSE juga menunjukkan variasi sesuai dengan nilai korelasi rendah pada tahun 2015, tertinggi pada tahun 2016 dan sedang pada tahun 2014. Pada prediksi hujan skala dasarian menunjukkan tingkat keandalan yang tidak jauh berbeda dengan prediksi hujan bulanan dengan nilai $r=0,65$, pada periode $\mathrm{La}$ Niňa dan $r=0,80$ pada periode El Niňo. Nilai RMSE dasarian lebih tinggi $(334 \mathrm{~mm})$ dari nilai RMSE bulanan (132 $\mathrm{mm}$ ). Hal ini menunjukkan variabilitas curah hujan dasarian lebih tinggi daripada curah hujan bulanan.

\section{DAFTAR PUSTAKA}

Aldrian, E., Susanto, R.D. (2003). Identification of three dominant rainfall regions within Indonesia and their relationship to sea surface temperature. International Journal of Climatology: A Journal of the Royal Meteorological Society. 23, 1435-1452. doi: $10.1002 /$ joc.950

Bordi, I., De Bonis, R., Fraedrich, K., Sutera, A. (2015). Interannual variability patterns of the world's total column water content: Amazon River basin. Theoretical and Applied Climatology. 122,441-455. doi: 10.1007/s00704-014-1304-y

Chang, C.-P., Wang, Z., McBride, J., Liu, C.-H. (2005). Annual Cycle Of Southeast Asiamaritime Continent Rainfall And The Asymmetric Monsoon Transition. Journal of climate. 18,287-301. doi: 10.1175/JCLI3257.1

Deliang, C., Inger, H. (2008). Empirical-statistical Downscaling. World Scientific Publishing Company.

Durai, V., Bhowmik, S., Hatwar, H. (2007). Distribution Of Precipitable Water Contents Over Indian Monsoon Region. Mausam. 58,241 . 
ECMWF. (2020). Total Column Water. https://apps.ecmwf.int/codes/grib/param$\mathrm{db} / ? \mathrm{id}=137$ (accessed 15 Januari 2020).

Hamada, J.-I., Mori, S., Kubota, H., Yamanaka, M.D., Haryoko, U., Lestari, S., Sulistyowati, R., Syamsudin, F. (2012). Interannual Rainfall Variability Over Northwestern Jawa And Its Relation To The Indian Ocean Dipole And El Niño-southern Oscillation Events. SOLA. 8,69-72. doi: 10.2151/sola.2012-018

Hidayat, R., Ando, K., Masumoto, Y., Luo, J. (2016). Interannual variability of rainfall over Indonesia: Impacts of ENSO and IOD and their predictability. IOP Conference Series: Earth and Environmental Science: IOP Publishing, 31(1). doi: 10.1088/17551315/31/1/012043

Hidayat, R., Prasetyaningtiyas, G.A. (2018). Pemodelan Stabilitas Lereng Regional berdasarkan Kondisi Geohidrologi (Studi Kasus Longsor Pangkalan-Sumatera Barat). Seminar Nasional Teknik Sipil 2018.

Irawan, A., Virgianto, R., Safril, A., Gustono, S., Putranto, N. (2019). Rainfall Threshold And Soil Moisture Indexes For The Initiation Of Landslide In Banjarmangu Sub-district, Central Java, Indonesia. IOP Conference Series Earth and Environmental Science 243. doi: 10.1088/1755-1315/243/1/012028

Jang, J.-S. (1993). ANFIS: Adaptive-networkbased Fuzzy Inference System. leee Transactions On Systems, Man, And Cybernetics. 23,665-685. doi: 10.1109/21.256541

Kadarsyah. (2010). Aplikasi Roc Untuk Uji Kehandalan Model Hybmg. Jurnal Meteorologi Dan Geofisika, 11(2), 33-43. doi: 10.31172/jmg.v11i1.60

Kinasih, J.S., Nhita, F., Adiwijaya, A., (2015). Prediksi Curah Hujan Menggunakan Adaptive Neuro Fuzzy Inference System (ANFIS). eProceedings of Engineering. 2.

Komalasari, K.E., Fajariana, Y., Nuraini, T.A., Anggraen, R. (2016). Aplikasi Metode Ensemble Mean Untuk Meningkatkan Reliabilitas Prediksi Hybmg Jurnal Meteorologi dan Geofisika, 17(1), 47-52. doi: 10.31172/jmg.v17i1.381

Kurniawan, F., Wibawa, A.P., Nugroho, S.M.S., Hariadi, M. (2017). Makassar Smart City Operation Center Priority Optimization Using Fuzzy Multi-criteria Decisionmaking. 2017 4th International Conference on Electrical Engineering, Computer Science and Informatics (EECSI): IEEE; 2017. doi: 10.11591/eecsi.4.1010

Liliwarti, L., Nengsih, S., Satwarnirat, S. (2016). Kestabilan Lereng Berdasarkan Intensitas Curah Hujan dan Permeabilitas Tanah.
Jurnal Rekayasa Sipil Politeknik Negeri Andalas. 13,139442.

Lu, N., Qin, J., Gao, Y., Yang, K., Trenberth, K.E., Gehne, M., Zhu, Y. (2015). Trends and variability in atmospheric precipitable water over the Tibetan Plateau for 2000 2010. International Journal of Climatology. 35,1394-1404. doi: 10.1002/joc.4064

Manzanas, R. (2017). Assessing The Suitability of Statistical Downscaling Approaches For Seasonal Forecasting in Senegal. Atmospheric Science Letters. 18,381-386. doi: $10.1002 / a s l .767$

Nuraini T.A., Nuryanto D.E., Komalasari K.E., Satyaningsih. R. Fajariana Y., Anggraeni R. Sopaheluwakan A. (2019). Pengembangan Model Hybmg 2.07 Untuk Prediksi Iklim di Indonesia Dengan Menggunakan Data Tropical Rainfall Measuring Mission (TRMM). Jurnal Meteorologi dan Geofisika, 20(2), 101-112. doi: 10.31172/jmg.v20i2.610

Navianti, D.R., Widjajati, F.A. (2012). Penerapan fuzzy inference system pada prediksi curah hujan di Surabaya Utara. Jurnal Sains dan Seni ITS. 1(1). doi: 10.12962/j23373520.v1i1.1005

NOAA. (2020). Oceanic El Niño Index (ONI). https://origin.cpc.ncep.noaa.gov/products/a nalysis_monitoring/ensostuff/ONI_v5.php (accessed 15 Januari 2020).

Nur'utami, M.N., Hidayat, R. (2016). Influences Of lod And Enso To Indonesian Rainfall Variability: Role Of Atmosphere-ocean Interaction In The Indo-pacific Sector. Procedia Environmental Sciences. 33,196203. doi: 10.1016/j.proenv.2016.03.070

Pandey, A., Agrawal, C., Agrawal, M. (2017) A Hadoop Based Weather Prediction Model for Classification of Weather Data. 2017 Second International Conference On Electrical, Computer And Communication Technologies (ICECCT): doi: 10.1109/ICECCT.2017.8117862

Priyono, K.D., (2008). Analisis Morfometri Dan Morfostruktur Lereng Kejadian Longsor Di Kecamatan Banjarmangu Kabupaten Banjarnegara. Forum Geografi. doi: 10.23917/forgeo.v22i1.4926

Priyono, K.D., Priyana, Y. (2006). Analisis Tingkat Bahaya Longsor Tanah di Kecamatan Banjarmangu Kabupaten Banjarnegara. Forum Geografi, 20(2).

Qian, J.-H., Robertson, A.W., Moron, V. (2010). Interactions among Enso, The Monsoon, And Diurnal Cycle In Rainfall Variability Over Java, Indonesia. Journal Of The Atmospheric Sciences, 67, 3509-3524. doi: 10.1175/2010JAS3348.1

Ralph, F.M., Galarneau Jr, T.J. (2017). The Chiricahua Gap and the role of easterly water vapor transport in southeastern Arizona monsoon precipitation. Journal of 
Hydrometeorology. 18, 2511-2520. doi: 10.1175/JHM-D-17-0031.1

Ridmardhani, E. (2015). Kajian Gerakan Massa Tanah pada Kawasan Permukiman di Desa Sijeruk Kecamatan Banjarmangu Kabupaten Banjarnegara Provinsi Jawa Tengah. Thesis, UPN" Veteran" Yogyakarta.

Riordan, D., Hansen, B.K., (2002). A Fuzzy Case-based System For Weather Prediction. Engineering Intelligent Systems For Electrical Engineering And Communications. 10, 139-146.

Safril, A., Kristianto, A., Septiadi, D., Suwandi, I.G., Ahadi, S., Pribadi, S., Rohadi, S., Munawar, H.S., Mulsandi, A., Nugroho, H.A. (2017). Kajian Awal Sistem Peringatan Dini Longsor Berbasis Penguatan Sistem Prediksi Curah Hujan dan Gempa Bumi (Studi Area: Garut dan Banjarnegara). Tangerang Selatan: STMKG.

Schmidli, J., Frei, C., Vidale, P.L., (2006). Downscaling From GCM Precipitation: A Benchmark For Dynamical And Statistical Downscaling Methods. International Journal Of Climatology: A Journal Of The Royal Meteorological Society, 26, 679-689. doi: 10.1002/joc. 1287

Soenarmo, S.H., Sadisun, I., Saptohartono, E., (2008). Kajian Awal Pengaruh Intensitas Curah Hujan Terhadap Pendugaan Potensi Tanah Longsor Berbasis Spasial Di Kabupaten Bandung, Jawa Barat. Jurnal Geoaplika, 3, 133-141.

Soto, J., Castillo, O., Soria, J. (2010). Chaotic Time Series Prediction Using Ensembles Of Anfis. In book: Soft Computing For Intelligent Control And Mobile Robotics: Springer; 2010. doi: 10.1007/978-3-642$15534-518$

Susanti, I., (2017). Pola Kelembapan di Benua Maritim Indonesia dan Sekitarnya (The Indonesian Maritime Continent and Its
Surroundings Moisture Patterns). Majalah Sains dan Teknologi Dirgantara. 10.

Susanti, P.D., Miardini, A., (2016). Analisis Tingkat Kerawanan dan Teknik Mitigasi Longsor di Sub Das Merawu. Prosiding Seminar Nasional Geografi UMS VII 2016.

Susanti, P.D., Miardini, A., Harjadi, B., (2017). Analisis Kerentanan Tanah Longsor Sebagai Dasar Mitigasi Di Kabupaten Banjarnegara. Jurnal Penelitian Pengelolaan Daerah Aliran Sungai. 1, 4959.

Swarinoto Y.B, Koesmaryono Y., Aldrian E., Wigena A.H, (2012). Model Sistem Prediksi Ensemble Total Hujan Bulanan dengan Nilai Pembobot (Kasus Wilayah Kabupaten Indramayu) Jurnal Meteorologi Dan Geofisika, 13(3). doi: 10.31172/jmg.v13i3.134

Wang, H., Chen, H. (2012). Climate Control for Southeastern China Moisture and Precipitation: Indian or East Asian Monsoon?. Journal of Geophysical Research: Atmospheres. 117(D12). doi: 10.1029/2012JD017734

Wang W., Chen, M., Kumar, A. (2010). An Assessment of The CFS Real-time Seasonal Forecasts. Journal of Weather and Forecasting, 25(3). doi: 10.1175/2010WAF2222345.1

Warnadi. (2014). Inventarisasi Daerah Rawan Longsor Kabupaten Banjarnegara Jawa Tengah. Jurnal Spatial Wahana Komunikasi dan Informasi Geografi. 12(2). doi: 10.21009/spatial.122.06

Wilks, D.S., (2011). Statistical Methods In The Atmospheric Sciences. Oxford: Academic Press.

Xie, B., Zhang, Q., Ying, Y., (2011). Trends In Precipitable Water And Relative Humidity In China: 1979-2005. Journal Of Applied Meteorology And Climatology. 50, 19851994. doi: 10.1175/2011JAMC2446.1 